\title{
EFFICIENCY OF INDIRECT IMMUNOFLUORESCENCE ASSAY AS A CONFIRMATORY TEST FOR THE DIAGNOSIS OF HUMAN RETROVIRUS INFECTION (HIV-1 and HTLV-I/II) IN DIFFERENT AT RISK POPULATIONS
}

\author{
René GASTALDELLO, Sandra GALLEGO, María Beatriz ISA, Silvia NATES \& Silvia MEDEOT
}

\begin{abstract}
SUMMARY
We compared the indirect immunofluorescence assay (IFA) with Western blot (Wb) as a confirmatory method to detect antibodies anti retrovirus (HIV-1 and HTLV-I/II). Positive and negative HIV-1 and HTLV-I/II serum samples from different risk populations were studied. Sensitivity, specificity, positive, negative predictive and kappa index values were assayed, to assess the IFA efficiency versus Wb. The following cell lines were used as a source of viral antigens: H9 ( HTLV-III b); MT-2 and MT-4 (persistently infected with HTLV-I) and MO-T (persistently infected with HTLV-II). Sensitivity and specificity rates for HIV-1 were $96.80 \%$ and $98.60 \%$ respectively, while predictive positive and negative values were $99.50 \%$ and $92.00 \%$ respectively. No differences were found in HIV IFA performance between the various populations studied. As for IFA HTLV system, the sensitivity and specificity values were $97.91 \%$ and $100 \%$ respectively with positive and negative predictive values of $100 \%$ and $97.92 \%$. Moreover, the sensitivity of the IFA for HTLV-I/II proved to be higher when the samples were tested simultaneously against both antigens (HTLV-I-MT-2 and HTLV-II-MO-T). The overall IFA efficiency for HIV-1 and HTLV-I/II-MT-2 antibody detection probed to be very satisfactory with an excellent correlation with $\mathrm{Wb}$ (Kappa indexes 0.93 and 0.98 respectively). These results confirmed that the IFA is a sensitive and specific alternative method for the confirmatory diagnosis of HIV-1 and HTLV-I/II infection in populations at different levels of risk to acquire the infection and suggest that IFA could be included in the serologic diagnostic algorithm.
\end{abstract}

KEYWORDS: Retrovirus ; HIV-1 ; HTLV-I/II ; Indirect immunofluorescence assay ; Diagnosis.

\section{INTRODUCTION}

Retroviruses are a large family, primarily of vertebrate viruses, although they are also found in other animals, such as insects and mollusks. Human retroviruses might be responsible for such biologic disorders as leukemia, immunosuppression, and dementia. The worldwide outbreak of the Acquired Immunodeficiency Syndrome (AIDS) is the result of infection with retroviruses HIV-1 and HIV-2 which belong to the lentivirus group. The HIV-1 virus is found all over the world, whereas the HIV-2, which was isolated in Western Africa in 1986, has now been found occasionally in most regions where it has been sought. A number of cases have been reported in Europe, America and $\mathrm{Asia}^{2,33,34}$.

On the other hand, the Human T-cell Lymphotropic Viruses type I (HTLV-I) and type II (HTLV-II) are closely related type C retroviruses belonging to HTLV-BLV group viruses. HTLV-I has been shown to be the etiologic agent for such diseases as aggressive adult $\mathrm{T}$ cell leukemia/lymphoma and HTLV-I associated myelopathy or tropical spastic paraparesis (HAM/TSP), but there are several arguments to suggest that the virus might have a wider disease range associated with the decay of connective tissue. In contrast, HTLV-II was isolated from two individu- als undergoing hairy T-cell leukemia, but it has not been consistently associated with any disease, though a neurologic disorder similar to HAM/TSP has been reported in several HTLV-II infected subjects $1,2,5,13-15,18,22,27,30-32,36$.

The diagnosis of these retroviruses infection is generally based on an specific antibody detection. Antibodies against various viral structure proteins are measured by a number of simple and sensitive initial screening tests. The commercially available enzyme immune assay (EIA) has been well established and widely used as a highly sensitive method for screening blood donors and high-risk individuals for antibody to human retroviruses ${ }^{3}$, but "false positive" results have been shown to occur with this test because of cross reactions to HLA antigens, some parasites such as Plasmodium and T. cruzi or other retroviruses. Other causes of false positive test results are repeated by freezing and thawing of the serum specimen, lipemic serum specimens, serum containing hemolyzed red blood cells, highly concentrations of immunocomplexes, etc ${ }^{3}$. Another commonly used method is the Particle Agglutination assay (PA). It has several major advantages including easy management and sensitivity to the detection of antibodies to whole viral antigens ${ }^{11}$. A reliable confirmatory, well accepted assay must be

Institute of Virology "Dr. J.M. Vanella”, Faculty of Medical Sciences, National University of Cordoba, Cordoba, Argentina.

Correspondence to: René Gastaldello, Instituto de Virología “Dr. J.M. Vanella”, Facultad de Ciencias Médicas, UNC. Avenida Valparaíso s/n. Ciudad Universitaria. 5016 Córdoba, Argentina. Tel/fax: 54-351-4334022/4569551; e-mail: smedeot@ cmefcm.uncor.edu. 


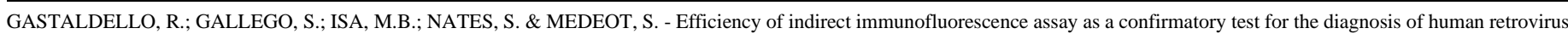
infection (HIV-1 and HTLV-I/II) in different at risk populations. Rev. Inst. Med. trop. S. Paulo, 41(3): 159-164, 1999.

used to retest all EIA-PA positive specimens because specificity is less than $100 \%$. Serological assays known to be effective for confirming positive results include: Immunofluorescence assay (IFA), Radioimmunoprecipitation assay (RIPA) and Western blot test (Wb)

Because of the ease of use and specificity of reactivity, the $\mathrm{Wb}$ is a standard "confirmatory" assay following initial HIV-1 screening ${ }^{25}$, but a lot of indeterminate results for HTLV-I/II have been reported by this technique ${ }^{21,24,37}$. Indeterminate serum samples may be caused by several factors including low antibodies titers, early seroconversion to the viral infection, other unknown closely related retrovirus, or antibodies against cellular components sharing epitopes with HTLV. Certain monoclonal antibodies against HTLV-I p19 have been demonstrated to recognize unique cellular antigens ${ }^{28}$. On the other hand, the IFA has been a useful and technically simple assay employed to detect antibodies to retroviruses, including HTLV ${ }^{6,8}$. The primary advantages of the IFA are the convenience and speed which test results may be attained. Moreover, the use of an uninfected cell control greatly ensures high assay specificity. Several reports have proved IFA to be very sensitive and specific as a confirmatory human retrovirus antibody assay, depending on the cell-derived viral antigen used ${ }^{3,4,7,10,17,20,23,26,29}$. Moreover, despite the close make up resemblance between HTLV-I and HTLV-II, IFA allows the discrimination between these two viral infections ${ }^{12}$. Nevertheless, in testing blood bank specimens and sera from local laboratories, many discrepancies were found between IFA and $\mathrm{Wb}^{10}$ indicating that the predictive values of IFA results should be verified, especially in individuals in low-risk groups.

The aim of this work was to evaluate the use of IFA test as a confirmatory human retroviruses antibody assay. We compared results obtained by $\mathrm{Wb}$ and IFA for detection of antibodies to HIV-1 and HTLV-I/II in several groups of sera, including those from high-risk individuals and low risk populations.

\section{MATERIALS AND METHODS}

\section{Cell lines}

The following HIV-1 and HTLV-I/II infected cell lines have been used as a source of viral antigens:

-MT-2 and MO-T prototype HTLV-I and HTLV-II persistently infected cell strains and the HT uninfected cell line were supplied by Dr. Renu B. Lal (CDC, Atlanta, USA).

-MT-4, another HTLV-I persistently infected cell strain and H9 (HTLV-III b) infected and H9 uninfected cell lines were kindly provided by Dr. Horacio Salomón, from the School of Medicine, University of Buenos Aires, Argentina.

All cell lines were cultured at $37^{\circ} \mathrm{C}$ and $5 \% \mathrm{CO}_{2}$ in RPMI 1640 with $20 \%$ Fetal Bovine Serum (FBS), 3\% L-glutamine and 25 mM HEPES. Cultures were doubled weekly by diluting them 1:2 in fresh medium.

\section{Serum panels}

The retrovirus antibody status of all the serum panels that were selected for this study were previously confirmed by $\mathrm{Wb}$. They included:
A) 15 serum specimens obtained from the CDC Performance Evaluation Program for HIV-1 testing.

B) 52 serum specimens obtained from the CDC Performance Evaluation Program for HTLV-I/II testing.

C) 164 sera from subjects at low risk for retroviral infection (blood donors).

D) 120 sera from various patients at high risk for both HIV-1 (n:107) and HTLV-I/II (n:13) infection (hemodialyzed subjects, i.v. users, homosexuals, hemophiliacs and prostitutes from Cordoba, and Tobas Indian tribes from Chaco Province, Argentina).

\section{Indirect Immunofluorescence Assay (IFA)}

Air dry acetone-fixed slides with either HTLV-III b H9 cell or HTLV-I/II infected cells were used as source of antigens. Uninfected H9 and HT cells were included on the slides as a control of inespecificity. The IFA smears were prepared according to the procedure that was described previously by GALLEGO et al. ${ }^{8}$. For the IFAs, the sera were diluted at 1:10 and 1:4 in phosphate buffered saline (PBS) for HIV-1 and HTLV-I/II respectively following the standard procedure. Briefly, $10 \mathrm{uL}$ of every specimen or control dilution was added onto a slide well coated with infected cells and $10 \mathrm{uL}$ onto a well coated with uninfected cells. The specimens were then incubated for $30 \mathrm{~min}$ at $37{ }^{\circ} \mathrm{C}$ in a humidity box. After being washed three times with PBS and them dried, FITC-conjugated anti human IgG $(10 \mathrm{uL})$ was added to each well and incubated at $37^{\circ} \mathrm{C}$ in a humidity box during $30 \mathrm{~min}$ followed by washing as above. A buffered glycerol ( $\mathrm{pH}:$ 8.0) solution was placed on the slides, followed by a cover slip. This procedure preserved fluorescence for several days. Sera were considered positive for HIV-1 and HTLV-I/II antibodies when characteristic cytoplasmic staining on infected cells and no IFA staining on uninfected cell lines were observed.

\section{RESULTS}

In this study a total of 256 and 95 sera confirmed by Wb for HIV-1 and HTLV-I/II respectively, were tested by IFA in order to compare assay sensitivity and specificity. The results obtained with the 256 sera confirmed by Wb for HIV-1 are shown in Table 1 . The overall sensitivity of IFA for anti HIV-1 antibody detection resulted in $96.80 \%$ with a specificity of $98.60 \%$, and with a positive and negative predictive value

Table 1

Comparison of IFA and Wb HIV-1 antibody results obtained on serum specimens from different populations from Cordoba, Argentina

\begin{tabular}{lcc} 
& \multicolumn{2}{c}{ Western blot } \\
\cline { 2 - 3 } IFA & Positive & Negative \\
\hline Positive & 181 & 1 \\
Negative & 6 & 68 \\
\hline
\end{tabular}

Sensitivity: $96.80 \%$

Specificity: $98.60 \%$

Positive predictive value: $99.50 \%$

Negative predictive value: $92.00 \%$

Kappa index: 0.93 


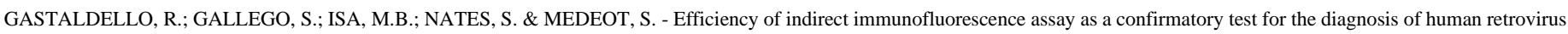
infection (HIV-1 and HTLV-I/II) in different at risk populations. Rev. Inst. Med. trop. S. Paulo, 41(3): 159-164, 1999.

(PPV and PPN) of $99.50 \%$ and $92.00 \%$ respectively. Moreover, there was a high correlation between IFA and $\mathrm{Wb}$ reactivity (Kappa index of $0.93)$

The HIV-1 IFA results for low and high risk individuals panel sera are shown in Table 2 and 3 respectively. Data, obtained from these two population specimens showed that the IFA specificity, sensitivity, predictive values and Kappa index versus $\mathrm{Wb}$ were comparable.

IFA HTLV-I/II test results onto MT-2 cell line are shown in Table 4. There was nearly full agreement between IFA and $\mathrm{Wb}$ on the 95 sera tested. Only one HTLV-I/II Wb positive serum showed no detectable antibody by IFA with a sensitivity of $97.91 \%$, a specificity of $100 \%$ and a PPV and PPN of $100 \%$ and $97.92 \%$ respectively. The Kappa index was 0.98 (Table 4). In order to assess the efficiency of different infected cell lines to detect anti HTLV-I/II antibodies by IFA, we assayed the antigenicity of MT-2 (HTLV-I), MT-4 (HTLV-I), MO-T (HTLV-II), and the 1:1 ratio mixture of MT-2 and MO-T cell suspension using serum panels from different HTLV-I/II infected individuals with positive or indeterminate HTLV-I/II Wb status. Results are shown in Table 5. From the $11 \mathrm{HTLV}-\mathrm{I} / \mathrm{II} \mathrm{Wb}$ indeterminate samples, 3 were negative (IFA antibody titer lower than 4) onto MT-2 cell line, 3 onto MT-4 cell line and 8 onto MO-T cell line, being all positive onto the MT-2/MO-T mixture smears. From the HTLV-I/II Wb positive sera tested, 5 were negative onto MO-T cell line, 1 onto MT-2 and the MT-2/MO-T mixture smears, whereas MT-4 cell line failed in the detection of 3 of them.

Table 2

Comparison of IFA and Wb HIV-1 antibody results obtained on serum specimens from blood donors from Cordoba, Argentina

\begin{tabular}{lcc} 
& \multicolumn{2}{c}{ Western blot } \\
\cline { 2 - 3 } IFA & Positive & Negative \\
\hline Positive & 113 & 0 \\
Negative & 2 & 19 \\
\hline
\end{tabular}

Sensitivity: $98.30 \%$

Specificity: $100 \%$

Positive predictive value: $100 \%$

Negative predictive value: $90.50 \%$

Kappa index: 0.96

Table 3

Comparison of IFA and Wb HIV-1 antibody results obtained on serum specimens from populations at high risk from Cordoba, Argentina

\begin{tabular}{lcc} 
& \multicolumn{2}{c}{ Western blot } \\
\cline { 2 - 3 } IFA & Positive & Negative \\
\hline Positive & 59 & 1 \\
Negative & 3 & 44 \\
\hline
\end{tabular}

Sensitivity: $95.20 \%$

Specificity: $98.00 \%$

Positive predictive value: $98.30 \%$

Negative predictive value: $93.62 \%$

Kappa index: 0.92
By using the comparison of IFA serum titer against MT-2 and MO-T antigen, eighteen out of 27 sera studied were typed as HTLV-I, 4 as HTLV-II, and the rest of the samples remained as HTLV-I/II (no differences in IFA antibody titer onto MT-2 and MO-T antigens were found) (Table 5).

\section{DISCUSSION}

Current confirmatory testing for retrovirus antibodies is based primarily on immunoblot ${ }^{3,19,20,23}$. We have demonstrated in this study that the IFA showed sensitivity and specificity comparable to $\mathrm{Wb}$ and could be used as a simple alternative or reference assay for the standard Wb test. The IFA and $\mathrm{Wb}$ test result determining Kappa index indicated a high level of agreement (more than 90\%) between the two methods for both viral systems (Tables 1 and 4).

The IFA has been used in diagnostic laboratories successfully for 2 decades and the potential utility of the IFA for the detection and quantification of HIV-1 antibodies has been well documented. Similarly, the capability of an IFA using HIV-1 infected CEM and H9 cells to serve as a confirmatory test to replace or complement the $\mathrm{Wb}$ test in various patients at high risk was recently reported ${ }^{4,29}$. However, it has not been sufficiently standardized for the use in low risk populations as blood donors. Moreover, it is well recognized that IFA and Wb test positive result agreement may vary significantly depending upon the population screened and the criteria used for interpreting indeterminate results ${ }^{16}$.

Our evaluation of the IFA for antibodies to HIV-1 proved to be a suitable procedure for the diagnosis of infected individuals regardless of their risk levels. Thus, the positive and negative predictive values did not vary between the populations studied (Tables 2 and 3 ).

Furthermore, the IFA test for the HTLV system proved to be an equally sensitive and specific alternative method to Western blotting. Although MT-2 and MO-T cell antigens were able to detect antibodies against both viral types (HTLV-I and HTLV-II), the sensitivity of the test was higher when antibodies were confronted with the homologous antigen. Therefore, MT-2 line has been shown to be more sensitive than MT-4 and MO-T lines to detect anti HTLV-I antibodies, whereas MO-T line proved to be more sensitive to detect anti-HTLV-II antibodies. The highest sensitivity of HTLV IFA test was obtained when sera were confronted with the mixture 1:1 of MT-2/MO-T cell lines which enable

Table 4

Comparison of IFA and $\mathrm{Wb}$ HTLV-I/II antibody results obtained on serum specimens from different populations from Argentina.

\begin{tabular}{lcc} 
& \multicolumn{2}{c}{ Western blot } \\
\cline { 2 - 3 } IFA & Positive & Negative \\
\hline Positive & 47 & 0 \\
Negative & 1 & 47 \\
\hline
\end{tabular}

Sensitivity: $97.91 \%$

Specificity: $100 \%$

Positive predictive value: $100 \%$

Negative predictive value: $97.92 \%$

Kappa index: 0.98 


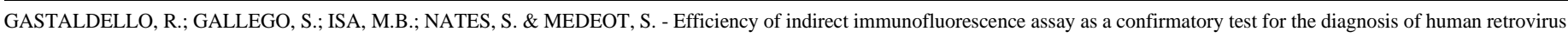
infection (HIV-1 and HTLV-I/II) in different at risk populations. Rev. Inst. Med. trop. S. Paulo, 41(3): 159-164, 1999.

Table 5

Differential antigenicity of three HTLV-I/II infected cell lines by indirect immunofluorescence assay using sera from distinct HTLV-I/II infected populations from Argentina

\begin{tabular}{|c|c|c|c|c|c|c|c|}
\hline \multicolumn{7}{|c|}{ Immunofluorescence antibody titers $(*)$} & \multirow[t]{3}{*}{ Typing } \\
\hline \multirow[t]{2}{*}{$\mathrm{n}$} & \multirow[t]{2}{*}{ Population } & \multirow[t]{2}{*}{$\mathrm{Wb}$} & \multicolumn{2}{|c|}{ HTLV-I } & \multirow{2}{*}{$\begin{array}{c}\text { HTLV-II } \\
\text { MO-T }\end{array}$} & \multirow{2}{*}{$\begin{array}{c}\text { HTLV-I/II } \\
\text { MT-2/MO-T }\end{array}$} & \\
\hline & & & MT-2 & MT-4 & & & \\
\hline 2 & Hemodial & + & $128-512$ & $>8$ & $8-64$ & $\geq 16$ & HTLV-I \\
\hline 1 & I.V. drugs & + & 1024 & $>8$ & 128 & $\geq 16$ & HTLV-I \\
\hline 1 & Hemophil & + & 32 & $>8$ & 4 & 8 & HTLV-I \\
\hline 2 & Blood donors & + & $64-128$ & $>8$ & $32-128$ & $\geq 8-\geq 32$ & HTLV-I/II \\
\hline 1 & Blood donors & + & 128 & $>8$ & 16 & $\geq 32$ & HTLV-I \\
\hline 1 & No data & + & $>4$ & $>4$ & $>4$ & $>4$ & HTLV-I/II \\
\hline 1 & Hemophil & + & 32 & $<4$ & 4 & 16 & HTLV-I \\
\hline 1 & Bisexual & + & 16 & $<4$ & $<4$ & $\geq 16$ & HTLV-I \\
\hline 1 & Toba & + & 8 & 4 & $<4$ & 16 & HTLV-I \\
\hline 1 & Blood donor & + & 128 & $>8$ & $<4$ & $\geq 8$ & HTLV-I \\
\hline 1 & No data & + & $>4$ & $>4$ & $<4$ & $>4$ & HTLV-I \\
\hline 1 & Blood donors & + & 32 & ND & ND & $>8$ & HTLV-I/II \\
\hline 1 & No data & + & $<4$ & $<4$ & $<4$ & $<4$ & HTLV-I/II \\
\hline 2 & Blood donors & I & 8 & $<4$ & $<4$ & $>8$ & HTLV-I \\
\hline 1 & No data & I & $<4$ & $<4$ & 64 & 16 & HTLV-II \\
\hline 2 & Toba & I & $<4$ & 4 & $8-64$ & 16 & HTLV-II \\
\hline 1 & Toba & I & 8 & 4 & $<4$ & $\geq 16$ & HTLV-I \\
\hline 5 & Blood donors & I & $8-128$ & $4->8$ & $<4$ & $>8$ & HTLV-I \\
\hline 1 & Toba & + & 256 & $>8$ & 1024 & $\geq 16$ & HTLV-II \\
\hline
\end{tabular}

(*) Numbers represent reciprocal of final positive serum dilution. Titers $\geq 4$ were considered significant.

ND: no done, +: positive, I: indeterminate.

us to define diagnosis in all $\mathrm{Wb}$ indeterminate samples. Consequently, according to GALLO ${ }^{12}$, when studying populations where both viral types may occur, both cell lines must be employed as IFA antigens.

The lack of antibody detection in one of the HTLV-I/II positive $\mathrm{Wb}$ serum by IFA using the MT-2/MO-T mixture was probably due to a low antibody title present in the sample and indicated that IFA offered an excellent reproducible method for detecting anti HTLV-I/II antibodies with a very low level of false negatives ${ }^{9,11,35}$.

Moreover, our data showed that the problem with HTLV indeterminate $\mathrm{Wb}$ results would be significantly reduced or even eliminated with the use of a confirmatory IFA test with both viral antigens (MT-2 and MO-T). It must be pointed out that HTLV-I/II indeterminate sera samples studied showed reactivity only against gene gag products and mainly against p19 (GALLEGO, S., unpublished data).
In a recent study it was reported that indeterminate HIV-1 and HTLV-I/II Wb results occurred as frequently as positive $\mathrm{Wb}$ results and most resolved if a second specimen was tested within 3-6 months, however, if specimen reactivity was directed against gene gag products, then longer periods of time were needed for resolution of antibody status $^{16}$.

On the other hand, differential reactivity of antibodies in sera against MT-2 and MO-T cells respectively allowed to distinguish between HTLV-I and HTLV-II infection as previously described ${ }^{12}$.

An important feature of our IFA assay is the use of an uninfected cell control well, so no HIV-1 or HTLV-I/II specimens required absorption with uninfected cell pack because of nonspecific staining.

Finally, the results that are shown here on the high level of agreement found between IFA and $\mathrm{Wb}$ for the detection of anti-retrovirus antibodies which turned out to be independent of the population studied, point 


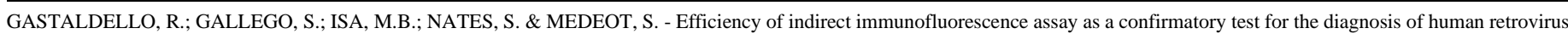
infection (HIV-1 and HTLV-I/II) in different at risk populations. Rev. Inst. Med. trop. S. Paulo, 41(3): 159-164, 1999.

out that IFA can replace $\mathrm{Wb}$ in the algorithm of confirmatory diagnosis of HIV-1 and HTLV-I/II infections. The latter, together with the advantage of IFA low cost implementation compared with other confirmatory methods, is a very important issue to take into account in designing health programs for developing countries such as Argentina.

\section{RESUMO}

\section{Eficiência da imunofluorescência indireta para o diagnóstico con- firmatório da infecção por retrovírus humanos (HIV-1) e (HTLV- I/II) em populações em diversos graus de risco à infecção}

Avaliou-se a eficiência da técnica de Imunofluorescência Indireta (IFI) como método confirmatório no diagnóstico da infecção por HIV-1 e HTLV-I/II. Para isto, processaram-se amostras com sorologia positiva ou negativa por Western blot (Wb) para ambos vírus, pertencentes a populações em diferentes graus de risco de adquirir a infecção e determinaram-se os valores de sensibilidade, especificidade, valores preditivos positivo e negativo e o índice de concordância Kappa da IFI para cada sistema viral em comparação com o Wb. Como fontes de antígenos da IFI empregaram-se as linhas celulares H9 (HTLV-III b), MT-2 e MT-4 (persistentemente infectadas com HTLV-I), MO-T (persistentemente infectadas com HTLV-II). Os valores globais de sensibilidade e especificidade para o sistema HIV-1, foram $96,80 \%$ e $98,60 \%$ respectivamente, enquanto os valores preditivos positivo e negativo $99,50 \% \mathrm{e}$ $92,00 \%$ respectivamente.

Não foram achadas diferenças na eficiência da técnica para a detecção de anticorpos anti HIV-1 entre as diversas populações estudadas.

A respeito do sistema MT-2-HTLV-I os valores achados de sensibilidade e especificidade da IFI foram de $97,91 \%$ e $100 \%$ respectivamente sendo os valores preditivos positivo e negativo de $100 \%$ e 97,92\% respectivamente. Do mesmo jeito para o sistema HTLV se demonstrou que a IFI implementada foi mais sensível quando se defrontaram as amostras com os dois antígenos virais (HTLV-I e HTLV-II) simultaneamente. A concordância global entre a IFI versus Wb para o sistema HIV-1 e HTLV foi ótima (índices de Kappa 0,93 e 0,98 respectivamente).

Estes resultados indicam que a IFI é uma técnica altamente sensível e específica resultando adequada para o diagnóstico confirmatório da infecção pelos retrovirus humanos HIV-1 e HTLV-I/II em populações em diferentes graus de risco, podendo substituir ao $\mathrm{Wb}$ no algoritmo proposto para o diagnóstico sorológico da infecção por estes agentes.

\section{ACKNOWLEDGMENTS}

The authors are grateful to Dr. Renu B. Lal and Horacio Salomon for providing the cell lines and to Drs. H. Bepre and Santos Sileoni for providing the sera. We also gratefully appreciate the excellent Portuguese language assistance of Dr. Victor O. Giayetto, and the collaboration of Dr. Marta Contigiani who facilitated us the use of the biological safety section apparatus.

This work received financial support from the Council of Science and Technology of the National University of Córdoba, Argentina; The Council of Science and Technology of Córdoba Province (CONICOR) and Dr. Raquel Elsa Rosso from the DASPU laboratory, UNC. Sandra
Gallego and René Gastaldello were supported by fellowships from CONICOR and National University of Córdoba respectively.

\section{REFERENCES}

1. BARTHOLEMEW, C.; SAXINGER, W.C.; CLARK, J.W. et al. - Transmission of HTLV-I and HIV among homosexual men in Trinidad. J. Amer. med. Ass., 257: 2604-2608, 1987

2. BLATTNER, W.A. - Retroviruses. In: EVANS, A.S., ed. Viral infections of humans: epidemiology and control. 3. ed. New York, Plenum, 1991. p. 545-592.

3. CARLSON, J.R.; YEE, J.; HINRICHS, S.H. et al. - Comparison of indirect immunofluorescence and Western blot for detection of anti-human immunodeficiency virus antibodies. J. clin. Microbiol., 25: 494-497, 1987.

4. CEBALLOS, A.; DEVITO, C.; PAMPURO, S. et al. - Evaluación de la IFI como prueba suplementaria para el diagnóstico de la infección por VIH-1. Rev. argent. Microbiol., 30: 59-63, 1998.

5. CORTES, E.; DETELS, R.; ABOULAFIA, D. et al. - HIV-1, HIV-2 and HTLV-1 infection in high risk groups in Brazil. New Engl. J. Med., 320: 953-958, 1989.

6. FAUREL, M. \& AZANNE, G. - Immunofluorescence assay for human immunodeficiency virus antibody: investigation of cell fixation for virus inactivation and antigen preservation. J. clin. Microbiol., 27: 1810-1813, 1989.

7. FORGHANI, B.; HURST, J. \& CHAN, C. - Advantages of a human immunodeficiency virus type1 (HIV-1) persistently infected Hela T4+ cell line for HIV-1 indirect immunofluorescence serology. J. clin. Microbiol., 29: 2266-2272, 1991.

8. GALLEGO, S.; RECALDE, A.; GASTALDELLO, R. et al. - Kinetics study of human antigens expression in $\mathrm{T}$ lymphocytics cell lines by indirect immunofluorescence assay. Viral Immunol., 10: 149-157, 1997.

9. GALLO, D.; DIGGS, J.L. \& HANSON, C.V. - Evaluation of two commercial human T-cell lymphotropic virus Western blot (immunoblot) kits with problem specimens. J. clin. Microbiol., 32: 2046-2049, 1994.

10. GALLO, D.; DIGGS, J.; KSHELL, G. et al. - Comparison of detection of antibody to the acquired immune deficiency syndrome virus by enzyme immunoassay, immunofluorescence, and Western blot methods. J. clin. Microbiol., 23: 1049-1051, 1986.

11. GALLO, D.; HOFFMAN, M.N.; COSSEN, C.K. et al. - Comparison of immunofluorescence, enzyme immunoassay, and Western blot (immunoblot) methods for detection of antibody to human T-cell leukemia virus type I. J. clin. Microbiol., 26: 1487$1491,1988$.

12. GALLO, D.; PENNING, L. \& HANSON, C. - Detection and differentiation of antibodies to human T cell lymphotropic virus types I and II by the immunofluorescence method. J. clin. Microbiol., 29: 2345-2347, 1991.

13. GESSAIN, A.; BARIN, F.; VERNANT, J.C. et al. - Antibodies to human T-lymphotropic virus type-I in patients with tropical spastic paraparesis. Lancet, 2: 407-410, 1985.

14. HINUMA, Y.; NAGATA, K.; HANAOKA, M. et al. - Adult T-cell leukemia: antigen in an ATL cell line and detection of antibodies to the antigen in human sera. Proc. nat. Acad. Sci. (Wash.), 78: 6476-6480, 1981.

15. HJELLE, B.; APPENZELLER, O.; MILLS, R. et. al. - Chronic neurodegenerative disease associated with HTLV-II infection. Lancet, 339: 645-646, 1992.

16. ILTIS, J.; PATEL, N.; LEE, S.; BARMANT, S. \& WALLEN, W. - Comparative evaluation of an immunofluorescence antibody test, enzyme immunoassay and Western blot for the detection of HIV-1 antibody. Intervirology, 31: 122-128, 1990. 


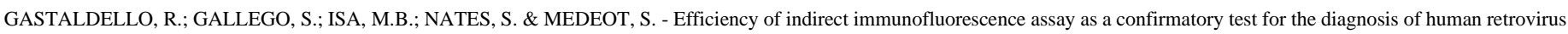
infection (HIV-1 and HTLV-I/II) in different at risk populations. Rev. Inst. Med. trop. S. Paulo, 41(3): 159-164, 1999.

17. KAMINSKY, L.; MC HUGH, D.T.; STITES, P.V.; HENLE, G. \& LEVY, J. - High prevalence of antibodies to acquired immune deficiency syndrome (AIDS)- associated retrovirus (ARV) in AIDS and related conditions but not in other disease states. Proc. nat. Acad. Sci. (Wash.), 82: 5535-5539, 1985.

18. KAWANO, F.; YAMAGUCHI, K.; NISHIMURA, H.; TSUDA, H. \& TAKATSUKI, K. - Variation in the clinical sources in adult T-cell leukemia. Cancer, 55: 851-856, 1985.

19. KHABBAZ, R.; HENEINE, W.; GRINDON, A. et al. - Indeterminate HTLV serologic results in U. S. blood donors: are they due to HTLV-I or HTLV-II? J. Acquir. Immune Defic. Syndr., 5: 400-404, 1992.

20. KVINESDAL, B.; NIELSEN, C.; POULSEN, A. \& HOJLYNG, N. - Immunofluorescence assay for detection of antibodies to human immunodeficiency virus Type 2 . J. clin. Microbiol., 27: 2502-2504, 1989.

21. LAIRMORE, M. \& LAL, R. - Other human retrovirus infections: HTLV-I and HTLV-II. In: SCHOCHETMAN, G. \& GEORGE, J.R., ed. AIDS testing: methodology and management. USA, 1991.

22. LEE, H.; SWANSON, P.; SHORT, V. et al. - High rate of HTLV-II infection in seropositive HIV drug abusers in New Orleans. Science, 244: 471-475, 1989.

23. LENNETTE, E.; KARPATKIN, S. \& LEVY, J. - Indirect immunofluorescence assay for antibodies to human immunodeficiency virus. J. clin. Microbiol., 25: 199-202, 1987.

24. LIPKA, J.; YOUNG, K.; KWOK, S.; REYES, G.R. et al. - Significance of human T-lymphotropic virus type I indeterminate serological findings among healthy individuals. Vox Sang. (Basel), 61: 171-176, 1991.

25. MAHONIS, J.; ROSENTHAL, K.; CHERNESKY, M. et al. - Agreement study between two laboratories of immunofluorescence as a confirmatory test for human immunodeficiency virus type 1 antibody screening. J. clin. Microbiol., 27: 1234-1237, 1989.

26. MEDEOT, S.; NATES, S.; GALLEGO, S. et al. - HTLV-I/II seropositivity in populations at high risk for HIV-1 infection in Cordoba City, Argentina. J. Acquir. Immune Defic. Syndr. hum. Retrovirol., 18: 187-188, 1998.

27. OSAME, M.; MATSUMOTO, M. \& YSUKU, K. - Chronic progressive myelopathy associated with elevated antibodies to human T-lymphocyte virus type I and adult T-cell leukemia-like cells. Ann. Neurol., 21: 117-122, 1987.
28. PALKER, T.; SCEARCE, E.; HO, W. et al. - Monoclonal antibodies reactive with human T cell lymphotropic virus I (HTLV-I) p19 internal core protein cross reactivity with normal tissues and differential reactivity with HTLV types I and II. J. Immunol., 135: $247-254,1985$.

29. PICCHIO, G. \& MUCHINIK, G. - Evaluación de IFI como ensayo confirmatorio en el diagnóstico serológico de la infección por el virus de la inmunodeficiencia humana (VIH). Medicina (B. Aires), 48: 120-124, 1988.

30. POISEZ, B.J.; RUSCETTI, F.W.; GAZDAR, A.F. et al. - Detection and isolation of type $\mathrm{C}$ retroviruses particles from the fresh and cultured lymphocytes of a patient with cutaneous T-cell lymphoma. Proc. nat. Acad. Sci. (Wash.), 77: 7415-7419, 1980.

31. ROBERT-GUROFF, M.; WEISS, S.H.; GIRON, J.A. et al. - Prevalence of antibodies to HTLV-I, II, and III in intravenous drug abusers from an AIDS endemic region. J. Amer. med. Ass., 255: 3133-3137, 1986.

32. SHEREMATA, W.; HARRINGTON, W.; BRADSHAW, P. et al. - Association of “(tropical) ataxic neuropathy” with HTLV-II. Virus Res., 29: 71-77, 1993.

33. VALLEJO, A.; GUTIERREZ, M. \& SORIANO, V. - HTLV-I/II infection among immigrants to Spain. Vox Sang. (Basel), 67: 79-80, 1994.

34. VERCAUTEREN, G.; BEELAERT, G. \& VAN DER GROEN, G. - Evaluation of an agglutination HIV- $1+2$ antibody assay. J. virol. Meth., 51: 1-8, 1995

35. VERDIER, M.; DENIS, F.; LEONARD, G. et al. - Comparison of immunofluorescence, particle agglutination, and enzyme immunoassays for detection of human $\mathrm{T}$ cell leukemia virus type I antibody in African sera. J. clin. Microbiol., 26: 1988-1993, 1990.

36. VERNAT, J.C.; MARUS, L.; GESSAIN, A. et al. - Endemic tropical spastic paraparesis associated with human T-lymphotropic virus type-I: a clinical and seroepidemiologic study of 25 cases. Ann. Neurol., 21: 123-130, 1987.

37. ZAAIJER, H.; CUYPERS, H.; WIT, C. \& LELIE, P. - Results of 1-year screening of donors in the Netherlands for human T-lymphotropic virus (HTLV) type I: significance of Western blot patterns for confirmation of HTLV infection. Transfusion, 34: 877-880, 1994.

Received: 01 December 1998

Accepted: 16 April 1999 